\title{
Exploring The Use Of Case Study Analysis In Consultant Skill Training
}

Debra S. Preston, (Email: preston@uncp.edu), University of North Carolina, Pembroke

\begin{abstract}
Analyzing practical business situations presented in case studies is increasingly common in professional training programs. Case study analysis can be an effective teaching method for developing business consultation skills. Presented in this article are the findings in recent professional literature related to using case studies in business education programs for consultation skill training.
\end{abstract}

\section{INTRODUCTION}

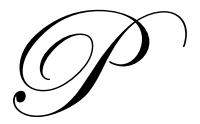

rofessional consultation practice usually involves a process wherein the consultant serves as an expert on a particular topic and interfaces with a consultee who is in need of services from the expert. The services can be in the form of assisting the consultee with a client problem, personal skill development, or with a system situation (Preston, 2004). The specific skills needed to effectively resolve any consultative endeavor include application of consultation theories, analysis of problem identification, development of intervention strategies, and intervention evaluation (Brown, 1993). These skills can be learned in educational programs that emphasize supervision of consultation practices (Stoltenberg, 1993; Conoley, Conoley, and Gumm, 1992). A method for providing students with supervised mock practice of consultation is to use case studies to simulate real-life scenarios. A review of literature on using case studies in professional training programs suggests that this method of instruction is on the rise but that there may be limitations in its use in education. These potential problems will be explored in this article as well as some suggestions for enhancing case studies used in education.

\section{RISE OF THE CASE STUDY ANALYSIS METHOD}

There has been a noted increase in the use of case studies in the development of skills in business education (Hassall \& Milne, 2004). Several advantages to this mode of instruction have been cited in the literature (Weil, Oyelere, \& Rainsbury, 2004). For example, case studies are a viable and common practice for learning consultation skills particularly when students are required to work collaboratively (Preston, 2004). Engaging students in structured learning groups rather than exposing them to passive learning can positively affect student confidence in problem solving (Perkins, 2002). There is also evidence that students will become even more active and independent learners if they lead case study analyzes in the classroom rather than being the recipients of teacher-led presentation (Adler, Whitney, \& Wynn-Williams, 2004). Additional benefits of the case study approach includes its ability to bridge the gap between theory and practice and its appeal to students' interest (Hassall, Lewis, \& Broadbent, 1998).

\section{POTENTIAL PROBLEMS WITH THE CASE STUDY ANALYSIS METHOD}

Potential pitfalls do exist in using the case study analysis method. Hassall, Lewis, and Broadbent (1998) noted that when the case study method is used as the sole teaching strategy, students may miss the broader goals of course instruction. Consultation training does involve learning technical skills of a specific topic in addition to applying problem-solving skills to a situation. Oftentimes, the activity of analyzing case studies is labor intensive and misdirects a significant amount of classroom instructional time that could be devoted to learning topic content. 
Another issue involved in the use of case studies is the content of the cases employed. For example, Ruhe and Allen (1999) noted that most business-related case studies lack positive female role models. Moreover, the gender and racial make-up of the characters may not reflect current labor force demographics.

Another potential problem with case relevancy was studied by Ballantine and Larres (2004). They postulated that students employed in the field would not perceive fictional case studies as approximations of "real-life" situations. However, despite concerns that students concurrently working in similar situations that are presented in fictional cases may not perceive the paper case as beneficial as "real" cases, most students reported a positive attitude toward the use of the case study method.

Mantano, Cardoso, and Joyce (2004) noted that traditionally instructors have relied on case studies of relatively short scenarios to develop skills such as positive communication, group collaboration and effective problem-solving. However, these skills are often not easily acquired. The authors advocate the use of longer cases that involve more complex situations; thus, enhancing the student development of skills.

\section{SUGGESTIONS FOR ENHANCING CASE STUDIES}

Cullen, Richardson, and O'Brien (2004) explored the debate that case studies used in education do not emboss the findings from empirical research. The authors concluded that a link between education and research exists when case studies are constructed based on information backed by empirical data. Using the authors' suggestion, case studies for consultant training can be created using empirical evidence. Keleher (1998) offered a solution for finding such suitable case studies. Universities that house highly-developed schools of business may have empirically-based commercial case studies that will fit the bill. Ones to try include Harvard, Stanford, and the University of Virginia.

Wynder (2004) advocated the use of computerized scenarios to simulate business situations as contemporary students tend to be attracted to learning through educational technology rather than in traditional classroom settings. The case study analysis software motivates students to find creative solutions to business problems. The system is designed to grade students for factually-correct information as well as for creativity in solving the problem. The computerized system could be programmed to dispense scenarios that call for consultation skills.

Finally, Hayes and Baker (2004) suggested using case studies that involve folk stories when exploring complex situations. The stories can be interpreted differently depending on the reader's individuality and thus, the potential exists for creating group conflict that students can then attempt to resolve. This ability to gain insight from the viewpoints of others is a skill that needs to be developed by consultants-in-training (Stoltenberg, 1993).

\section{CONCLUSION}

Using case study analysis is an effective classroom strategy for developing consultation skills in business education. Students have the opportunity to receive supervision when demonstrating skills in problem identification, intervention strategies, and communication skills. Potential limitations to case study analysis include the labor intensity of the method and the possible lack of suitable content in the case studies. However, the professional literature suggests that these potential pitfalls can be addressed. Writings about case study analysis instruction also suggest that the ways to enhance the method include using empirically based case studies, computerized case studies, and folk stories as case studies. 


\section{REFERENCES}

1. $\quad$ Adler, R. W., Whiting, R. H., \& Wynn-Williams, K. (2004). Student-led and teacher-led case presentations: Empirical evidence about learning styles in an accounting course. Accounting Education. Special Issue: Using Case Studies in Accounting Education, 13(2), 217-230.

2. Ballantine, J. A. \& Larres, D. M. (2004). A critical analyses of students' perceptions of the usefulness of the case study method in an advanced management accounting module: The impact of relevant work experience. Accounting Education. Special Issue: Using Case Studies in Accounting Education, 13(2), 171-189.

3. Brown, D. (1993). Training consultants: A call to action. Journal of Counseling and Development, 72(2), 139-144.

4. Conoley, C. W., Conoley, J. C., \& Gumm, W. B. (1992). Effects of consultee problem presentation and consultant training on consultant problem definition. Journal of Counseling and Development, 71, 60-62.

5. Cullen, J., Richardson, S., \& O’Brien, R. (2004). Exploring the teaching potential of empirically-based case studies. Accounting Education. Special Issue: Using Case Studies in Accounting Education, 13(2), 251-266.

6. Hassall, T., Lewis, S., \& Broadbent, J. M. (1998). The use and potential abuse of case studies in accounting education. Accounting Education, 7, 37-47.

7. Hassall, T. \& Milne, M. J. (2004). Using case studies in accounting education. Accounting Education. Special Issue: Using Case Studies in Accounting Education, 13(2), 135-138.

8. Hayes, R. S. \& Baker, C. R. (2004). Using a folk story to generate discussion about substance over form. Accounting Education. Special Issue: Using Case Studies in Accounting Education, 13(2), 267-284.

9. $\quad$ Keleher, J. (1998). Studies on the web. Information Outlook, 2(12), 30-32.

10. Mantano, J. L. A., Cardoso, S. M. J., \& Joyce, J. (2004). Skills development, motivation, and learning in financial statement analysis: An evaluation of alternative types of case studies. Accounting Education. Special Issue: Using Case Studies in Accounting Education, 13(2), 191-212.

11. Perkins, R. J. M. (2002/June). Psychoeducation: From classroom to treatment group. College Student Journal, 1-9.

12. Preston, D. S. (2004). Using a progressive collaborative case study approach as a teaching method in the helping professions. Proceedings for the 2004 Teaching and Learning Conference, 1(400), 1-3. Littleton, CO: Western Academic Press.

13. Ruhe, J. A. \& Allen, W. R. (1999). Representation of women in international business case studies. Journal of Education for Business, 75(2), 1-14.

14. Stoltenberg, C. D. (1993). Supervising consultants in training: An application of a model of supervision. Journal of Counseling and Development, 72(2), 131-139.

15. Weil, S., Oyelere, P., \& Rainsbury, E. (2004). The usefulness of case studies in developing core competencies in a professional accounting programme: A New Zealand study. Accounting Education. Special Issue: Using Case Studies in Accounting Education, 13(2), 139-169.

16. Wynder, M. (2004). Facilitating creativity in management accounting: A computerized business simulation. Accounting Education. Special Issue: Using Case Studies in Accounting Education, 13(2), 231-250. 


\section{NOTES}

